Article

\title{
Results from Interventions Addressing Social Skills to Reduce School Bullying: A Systematic Review with Meta-Analysis
}

\author{
Jorge Luiz da Silva ${ }^{1,2, \text {, }}$ \\ Orcid.org/0000-0002-3727-8490 \\ Wanderlei Abadio de Oliveira ${ }^{1}$ \\ Orcid.org/0000-0002-3146-8197 \\ Marcela Almeida Zequinão 5 \\ Orcid.org/0000-0003-3570-5425 \\ Elisângela Aparecida da Silva Lizzi ${ }^{3}$ \\ Orcid.org/0000-0001-7064-263X \\ Beatriz Oliveira Pereira ${ }^{2}$ \\ Orcid.org/0000-0003-4771-9402 \\ Marta Angélica Iossi Silva ${ }^{1}$ \\ Orcid.org/0000-0002-9967-8158
}

\begin{abstract}
${ }^{1}$ Universidade de São Paulo, Ribeirão Preto, SP, Brasil
${ }^{2}$ Universidade do Minho, Braga, Portugal

${ }^{3}$ Universidade Tecnológica Federal do Paraná, Cornélio Procópio, PR, Brasil

${ }^{4}$ Universidade de Franca, Franca, SP, Brasil

${ }^{5}$ Universidade do Oeste de Santa Catarina, Joaçaba, SC, Brasil
\end{abstract}

\begin{abstract}
Bullying, a public health problem, affects social relationships, school performance and students' health. The objective of this literature review was to verify whether interventions addressing social skills reduce victimization and/or aggression resulting from bullying. The following databases were consulted: LILACS, PsycINFO, Scielo, SCOPUS and Web of Science. The random-effects model and DerSimonianLaird method were used. Six studies that met the inclusion criteria were selected, the methodological quality of which was assessed using the Downs and Black scale. Results indicated that interventions addressing social skills reduced bullying and victimization, however, at non-significant levels. Interventions addressing social skills may be more effective if developed together with other types of intervention which may include a wide range of situations, contexts, as well as the different individuals involved in the bullying incident, such as school staff and family.
\end{abstract}

Keywords: Bullying, social skills, intervention, meta-analysis.

* Mailing address: Programa de Pós-Graduação em Promoção de Saúde, Universidade de Franca, Avenida Dr. Armando Salles Oliveira, 201, Parque Universitário, Franca, SP, Brasil 144040-600. Fone: (16) 3011-8728; Fax: (16) 3011-8728. E-mail: jorge.silva@unifran.edu.br

Projeto financiado pela Fundação de Amparo à Pesquisa do Estado de São Paulo (FAPESP). Processos 2013/22361-5 e 2015/01794-6. 


\title{
Resultados de Intervenções em Habilidades Sociais na Redução de Bullying Escolar: Revisão Sistemática com Metanálise
}

\begin{abstract}
Resumo
O bullying, considerado problema de saúde pública, afeta o relacionamento social, o desempenho escolar e a saúde de crianças e adolescentes. Esta revisão de literatura com metanálise objetivou verificar se intervenções em habilidades sociais reduzem a vitimização e/ou agressão por bullying. Foram consultadas as bases de dados: LILACS, PsycINFO, Scielo, SCOPUS e Web of Science. Na metanálise, empregou-se o modelo de efeitos aleatórios e o método de DerSimonian-Laird. Selecionou-se os seis estudos que atenderam aos critérios de inclusão, cuja qualidade metodológica foi avaliada pela escala de Downs e Black. Os resultados indicaram efeitos das intervenções em habilidades sociais na redução de agressão e vitimização, porém em níveis não significativos. Intervenções em habilidades sociais podem ser mais eficazes se desenvolvidas em conjunto com outras que envolvam também a variedade de situações, contextos e sujeitos implicados no bullying, como equipe escolar e família.
\end{abstract}

Palavras-chave: Bullying, habilidades sociais, intervenção, metanálise.

\section{Resultados de Intervenciones en Habilidades Sociales Aplicadas a la Reducción del Acoso Escolar: Revisión Sistemática con Metaanálisis}

\section{Resumen}

El Bullying o acoso escolar, considerado un problema de salud pública, afecta a las relaciones sociales, al desarrollo escolar y a la salud en general de niños y adolescentes. Esta revisión sistemática de literatura con metaanálisis tiene como objetivo comprobar si las intervenciones en habilidades sociales reducen la victimización y/o la agresión en los casos de acoso escolar. Se consultaron las bases de datos LILACS, PsycINFO, Scielo, SCOPUS y Web of Science. En el metaanáisis se empleó el modelo de efectos aleatórios y el modelo de DerSimonian-Laird. Se seleccionaron los seis estudios que corresponden a los critérios de exclusión cuya calidad metodológica fue evaluada en la escala de Downs y Black. Los resultados indicaron efectos positivos en las intervenciones pero a un nivel muy poco significativo. Las intervenciones podrían ser más eficaces si se desarrollan en conjunto con otras que aporten variedad en cuanto a situaciones, contextos y sujetos implicados en el acoso escolar tales como el personal docente y la familia.

Palabras clave: Acoso escolar, habilidades sociales, metaanálisis.

Relationship problems experienced among peers at school are a reality experienced by many children and adolescents. A severe problem in this context is that conflict situations marked by violence and bullying are the most frequent form of violence in the school environment (Olweus, 2013). This phenomenon represents a type of violence perpetrated among peers that occurs in the face of intentional and repetitive abusive behavior within an unequal relationship of power in which students may take part as victims, bullies, victim/bully and/or bystanders (Silva, Oliveira, \& Longarezi, 2008).

The average prevalence of school bullying in North America and Europe identified by a cross-sectional study conducted in 28 countries addressing a sample of 123,227 students was approximately $40 \%$ (Due et al., 2005). The occurrence of bullying in Brazil was mapped by the National School Health Survey (PeNSE), which determined in its second edition, conducted in 2012 , that $28 \%$ of a sample of 109,104 students 
from public and private schools spread throughout all the Brazilian states took part in bullying situations (Oliveira et al., 2015). The presence of bullying leads students to perceive the school environment as an unsafe place (Skrzypiec, Slee, Murray-Harvey, \& Pereira, 2011).

These data reveal a troubling context for professionals in the fields of education, psychology and health, as well as for those developing public policies in different areas, considering that in addition to its high prevalence, bullying negatively affects students' education, psychosocial development, and health conditions. That is, bullying is associated with depression, anxiety, loneliness, transgressive behavior, lack of discipline, school failure and abandonment, use of alcohol and other drugs, self-mutilation, and suicide (Benedict, Vivier, \& Gjelsvik, 2015; Silva \& Bazon, 2014; Silva, Silva, Pereira, Oliveira, \& Medeiros, 2014).

The literature reports that poor social skills are one of the causes of bullying, so that children and adolescents with this characteristic are more vulnerable to abuse (Stan \& Beldean, 2014). Social skills represent "the different social class behaviors of an individual's repertoire, which contribute to social competence, promoting a healthy and productive relationship with others" (Del Prette \& Del Prette, 2013, p. 31). Some examples of social class behaviors are communication skills, civility, assertive coping skills, and empathy, among others. Social competence has an evaluative meaning because it corresponds to the individuals' ability to use internal resources (thoughts and feelings), together with external resources (social and cultural aspects), in order to achieve a personal goal with positive consequences for themselves and others (Del Prette \& Del Prette, 2013).

Victims of bullying lack proper social skills, characterized by social isolation and inefficient coping strategies such, as: crying or ignoring bullies (Fox \& Boulton, 2003). In general, these strategies indicate that a victim is not socially competent, as they signalize to bullies that they lack self-defense abilities, which contributes to intensified violence (Crawford \& Manassis, 2011). Therefore, improved social skills, espe- cially assertiveness, represent an important aspect to ground interventions intended to reduce victimization (Silva et al., 2016). There is no consensus in the literature in regard to bullies, but there are indications that these individuals do not effectively deal with interpersonal challenges and an improvement in their social skills, especially empathy, may decrease bullying (Stan \& Beldean, 2014).

Despite the potential of interventions focused on social skills to prevent and reduce victimization and abusive behavior within the school environment, as reported by studies, there are no literature reviews addressing the effectiveness of intervention programs addressing social skills as a means to decrease school bullying. The identification of successful and also unsuccessful anti-bullying initiatives is essential to devising new proposals or reproducing the most effective ones. Hence, this study's objective was to verify whether social-skills interventions reduce victimization and/or abusive behavior.

\section{Method}

\section{Study Design}

This is a systematic literature review with meta-analysis. A systematic review consists of a rigorous synthesis of studies addressing a given topic, in which there is an attempt to avoid biases that may occur in the selection and analysis of papers. The general principles are: variety of databases, establishment of inclusion and exclusion criteria, and assessment of the studies' methodological quality. A meta-analysis was included in this systematic review because it is an appropriate statistical technique that combines the results of different studies (Galvão \& Pereira, 2014).

\section{Databases and Bibliographic Search}

Papers addressing the topics under study were found in October 2015 in four international databases (LILACS, PsycINFO, SCOPUS and Web of Science) and one Brazilian electronic library (SciELO). The following terms were cross-searched: Bullying AND Social Skills; 
Bullying AND Social Skills Training and their equivalents in Portuguese. The following guiding question was used: "What are the results presented by social-skills interventions implemented in schools to reduce school bullying?" The establishment of this question was based on the PICO (Patient or Problem, Intervention, Control or Comparison, Outcomes) strategy (Santos, Pimenta, \& Nobre, 2007).

\section{Inclusion and Exclusion Criteria}

Only scientific papers were included in this review so that others texts such as letters to the editor, books, book chapters, theses and dissertations were discarded. Additionally, only studies specifically addressing bullying, rather than other types of violence (e.g., homophobic abuse), were selected. Another inclusion criterion was discussing social skills interventions with experimental or quasi-experimental designs, the results of which were compared to students who did not take part in the intervention (control group). Hence, before and after studies not including a control group were excluded because these would not permit comparisons with other subjects with similar characteristics, an aspect that hinders the interpretation of data (Ttofi \& Farrington, 2011). Restrictions were not imposed in regard to year of publication, though only papers written in English, Spanish or Portuguese were included.

\section{Extraction of Data}

Studies were initially selected by reading their titles and abstracts, taking into account inclusion and exclusion criteria, after which, the full texts were then analyzed. An instrument was developed with the objective to extract the following data: author(s), year of publication, country of origin, sample size (intervention and control groups), subjects' ages, characteristics of the intervention, main results, and limitations.

\section{Assessment of Methodological Quality}

The studies' methodological quality was assessed using the scale developed by Downs and Black (1998) to assess intervention studies. It is an instrument composed of 27 questions divided into five dimensions: study's description (objective, outcome, inclusion criteria, type of intervention, confounding factors, variability of results, intervention's adverse effects, type of intervention, sample loss, and statistical probability), external validity (sample representativeness and how appropriate was the setting in which data was collected), internal validity (blind procedures, how appropriate data analysis was, participants' adherence, and measures' accuracy), selection bias (recruitment of subjects, sample loss, randomization and adjustment for confounding factors) and the study's statistical power. Each question scores one if its criterion is met, so that the instrument's total score is 27 points; the higher the score, the better the study's methodological quality.

\section{Statistical Analysis}

The random effect model and the DerSimonian-Laird method were used to perform the meta-analysis, assuming that the effect of interest is the same for all the studies and that differences between them are due to sample errors only (variability within the studies). Viechtbauer's (2010) metaphor package, written for the R statistical software (version 3.1.3), was used to calculate the differences between the means of the experimental and control groups before and after the social skills interventions were implemented. The results are graphically displayed using Forest Plots. Cochran's Q test and I-square were used to assess the studies' heterogeneity and magnitudes. According to $\mathrm{I}^{2}$, heterogeneity was considered low if close to $25 \%$, moderate if close to $50 \%$, and high when close to $75 \%$ (Higgins \& Thompson, 2002). The level of significance was established at $5 \%$.

\section{Results}

The bibliographic search resulted in 613 publications, but only six of these met the inclusion criteria (Figure 1). 


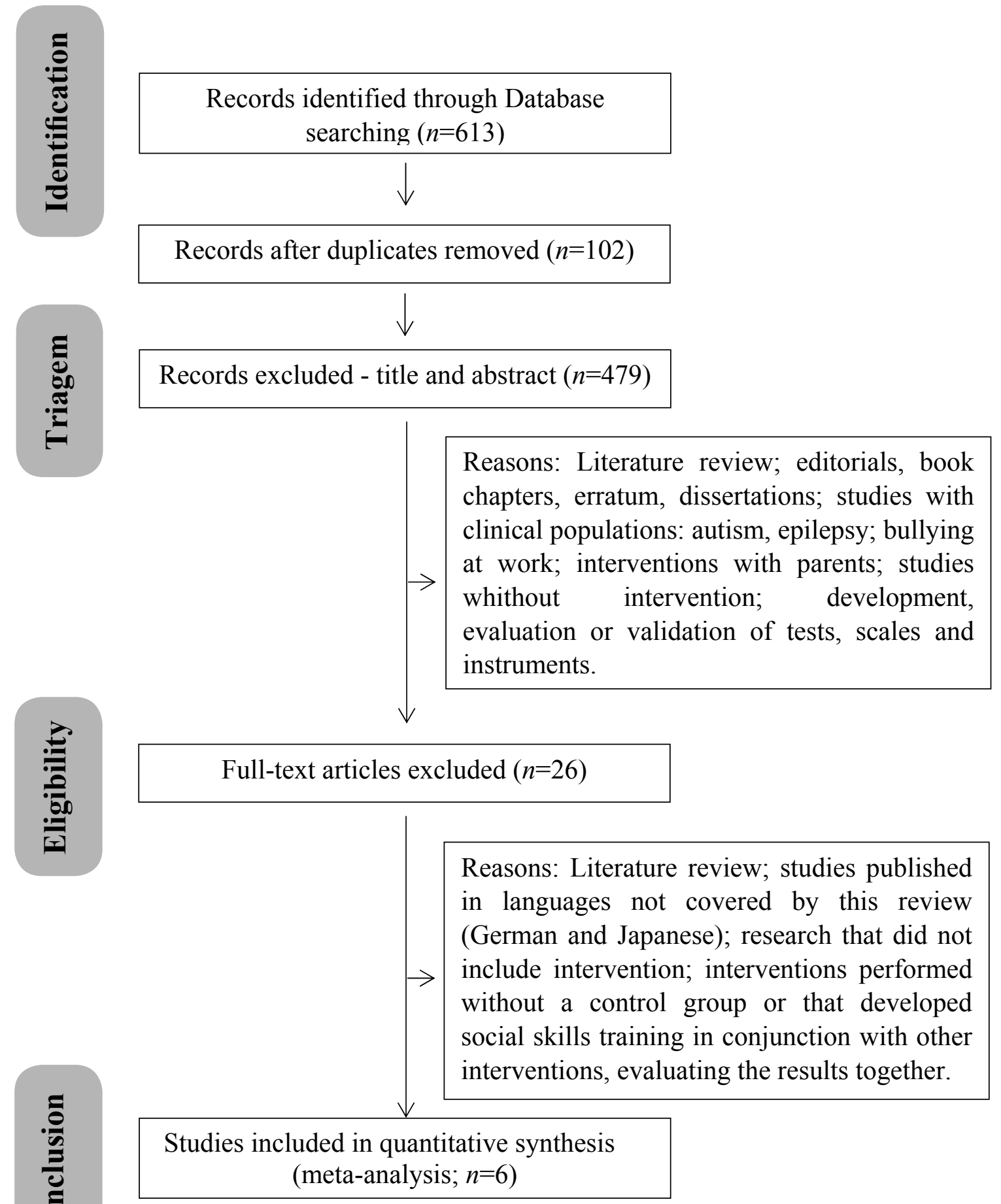

Figure 1. Flowchart concerning the studies' selection process.

In regard to the six studies included in this review (Table 1), the oldest was published in 2003 and the most recent was published in 2014. All the papers were written in English, though the studies related to them were conducted in different sociocultural contexts: Australia, United States, England, Italy, Japan and Romania. Sample sizes ranged from 28 to 381 subjects who were assigned to intervention and control groups. Two studies addressed children only; another two addressed adolescents only; the other two studies included both populations, as the participants' ages were from 8 to 16 years old. Half the interventions was developed with victims, bullies and bystanders, while two studies addressed only victims and the remaining study addressed bullies only. 
Table 1

Characteristics of the Studies Selected for the Systematic Review and Meta-Analysis

\begin{tabular}{lcccccc}
\hline Study & Year & Country & Sample & Age & Research Design & Target \\
\hline $\begin{array}{l}\text { Ando, Asakura, Ando, } \\
\text { \& Simons-Morton }\end{array}$ & 2007 & Japan & 104 & $12-13$ & Quasi-Experimental & Agresssion \\
Baldry \& Farrington & 2004 & Italy & 237 & $10-16$ & Experimental & $\begin{array}{c}\text { Agresssion and } \\
\text { victimization }\end{array}$ \\
Berry \& Hunt & 2009 & Australia & 46 & $12-15$ & Experimental & Victimization \\
$\begin{array}{l}\text { Fox \& Boulton } \\
\text { DeRosier }\end{array}$ & 2003 & England & 28 & $9-11$ & Quasi-Experimental & $\begin{array}{c}\text { Victimization } \\
\text { Agresssion and } \\
\text { victimization }\end{array}$ \\
Stan \& Beldean & 2004 & United States & 381 & $8-11$ & Experimental & $\begin{array}{c}\text { Agresssion e } \\
\text { victimization }\end{array}$ \\
\hline
\end{tabular}

The main results of each study are presented as follows.

Ando et al. (2007) assessed one social skills intervention program structured into four weekly sessions that addressed problem-solving, stress management, and communication. A total of 104 Japanese, $7^{\text {th }}$ grade students (victims, bullies and bystanders) from the city of Tokyo, were assigned to the intervention $(n=52)$ and control $(n=52)$ groups. Among other objectives, the program was intended to decrease bullying. The results indicated abusive behavior was reduced, as also occurred in the control group, while no statistical significance was found in favor of social skills training.

Aiming to improve social skills and promote a better understanding of the negative consequences of bullying and violence, the program developed by Baldry and Farrington (2004) included a sample of 237 children and adolescents from three schools from Rome, Italy. The students (victims, bullies and bystanders), aged between 10 and 16 years old, were randomly distributed between the intervention $(n=131)$ and control $(n=106)$ groups. The intervention was implemented in the course of three weekly sessions lasting three hours each. The participants received a booklet with content that was addressed in the meetings. The results reveal that the intervention's positive effects increased with age, and victimization and aggressions decreased significantly $(\mathrm{p}<.05)$ only among older students.
In the case of younger students, victimization even worsened in the experimental group.

The intervention developed by Berry and Hunt (2009) focused on the individuals' characteristics with the potential to increase one's vulnerability to bullying (victims), such as: anxiety, low self-esteem, and inadequate coping strategies. The activities developed in eight weekly sessions with a duration of one hour each were intended to reinforce personal competencies, increase the use of assertive coping strategies in bullying situations, and reduce the victims' levels of anxiety. The study sample was recruited in seven schools in the city of Sydney, Australia and was composed of 46 male students from the $7^{\text {th }}$ to the $10^{\text {th }}$ grade, whom experienced bullying and reported symptoms of anxiety; the students were randomly assigned to the intervention $(n=22)$ and control $(n=24)$ groups. The results show that the intervention significantly reduced victimization $(p<.001)$.

Fox and Boulton (2003) developed social skills training that was implemented in four English schools and included 15 students aged nine years and six months, on average. The participants were victims of bullying and the program was designed to improve their social skills in order to reduce their vulnerability to bullying. The skills addressed during the eight weekly meetings with a duration of one hour were: problem solving, positive thinking, relaxing, body language, making friends, and dealing with abusive 
individuals The results concerning victimization did not reveal statistically significant differences after the intervention when compared to the control group $(n=13)$.

DeRosier (2004) assessed the effects of a social skill training program developed with children (victims, bullies, and uninvolved individuals) attending the $3^{\text {rd }}$ grade and previously identified as being anxious, rejected by peers, or aggressive. Eight weekly one-hour group sessions each addressed social skills, emotional regulation and the identification of negative

Table 2

Criteria to Assess the Studies (n=6; Downs \& Black, 1998)

Sub-scales

Hits $(\%)$

Study description

$\begin{array}{ll}\text { Presents hypothesis/objectives } & 100\end{array}$

Well-defined outcomes 100

$\begin{array}{ll}\text { Well-defined inclusion criteria } & 100\end{array}$

Well-defined type of intervention $\quad 100$

$\begin{array}{ll}\text { Clear description of confounding factors } & 33,3\end{array}$

$\begin{array}{ll}\text { Well-described main findings } & 100\end{array}$

Presents estimates concerning the variability of results $\quad 100$

$\begin{array}{ll}\text { Reports the intervention's adverse effects } & 33,3\end{array}$

$\begin{array}{ll}\text { Describe losses } & 33,3\end{array}$

Presents a confidence interval of $95 \%$ or p-value $\quad 100$

External validity

$\begin{array}{ll}\text { The individuals invited to the study represent the population } & 66,7\end{array}$

$\begin{array}{ll}\text { The study participants represent the population } & 66,7\end{array}$

$\begin{array}{ll}\text { Representative settings/facilities } & 100\end{array}$

Internal validity

Blinding of participants $\quad 0,0$

Blinding of evaluators $\quad 0,0$

$\begin{array}{ll}\text { Results based on data dredging } & 100\end{array}$

$\begin{array}{ll}\text { Adjustment for follow-up duration } & 100\end{array}$

Appropriate statistical tests $\quad 100$

Reliable adherence to interventions $\quad 100$

Accurate outcomes measures 100

Selection bias

Intervention/control groups recruited from the same population $\quad 100$

Intervention/control groups recruited at the same time 100

Randomization $\quad 33,3$

$\begin{array}{ll}\text { Complete and irrevocable randomization } & 33,3\end{array}$

$\begin{array}{ll}\text { Adjustment for confounding factors } & 33,3\end{array}$

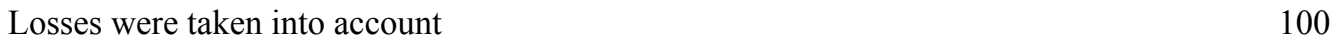

$\begin{array}{ll}\text { Study power } & 33,3\end{array}$ 
thoughts. The children were randomly distributed between the intervention $(n=187)$ and control $(n=194)$ groups. Eleven schools from Wake County in North Carolina, USA participated in the study. The intervention decreased the occurrence of bullying at a significant level $(p<.05)$ only for children who were initially identified as aggressive.

The study conducted by Stan and Beldean (2014) was intended to develop the students' social skills and, consequently, decrease the occurrence of bullying. For that, an intervention was designed to enable students to identify negative thoughts, to improve emotional regulation and assertiveness. A total of 231 students (victims, bullies and bystanders) from the $5^{\text {th }}$ to the $8^{\text {th }}$ grade from two schools in the city of ClujNapoca, Romania: 117 were assigned to the experimental group and 114 to the control group. Weekly sessions, totaling 18 hours, were implemented. The results indicate that victimization and aggressions decreased among those in the intervention group, however, not at significant levels when compared to the control group's results.

In regard to the assessment of the methodological quality of the selected studies, the scale developed by Downs and Black (1998) indicated a median score of 22 , within a score ranging from 19 to 24 points, while the total possible score is 27 (Table 2). The most frequently found weaknesses were: confounding factors were not reported; intervention's adverse effects were disregarded; sample losses were not reported; participants and evaluators were not blind; lack of randomization; lack of adjustment for confounding factors; and the study's statistical power was not reported.

In order to assess the effects of the social skills interventions implemented to decrease bullying, the results of this systematic review were analyzed in the meta-analysis by using the random effects model and the DerSimonianLaird method. The Forest Plots inserted in Figures 2 and 3 present the analysis of the effects of interventions in regard to aggressions and victimization compared to other students who did not take part in the interventions (control group). The horizontal lines represent the average difference for each study between the experimental and control group after the intervention, with their respective confidence intervals (CI95\%). Data located at the right of the vertical line indicate that the intervention was successful in reducing bullying and the combined effect of all the studies is represented by the diamond on the line denoted Total.

\begin{tabular}{|c|c|c|c|c|c|c|c|c|c|}
\hline \multirow[t]{2}{*}{ Study } & \multicolumn{3}{|c|}{ Intervention } & \multicolumn{3}{|c|}{ Control } & \multirow{2}{*}{$\begin{array}{c}\text { Weigth } \\
(\%)\end{array}$} & \multirow{2}{*}{$\begin{array}{c}\text { Difference } \\
95 \% \mathrm{IC}\end{array}$} & \multirow{2}{*}{$\begin{array}{c}\text { Difference } \\
95 \% \mathrm{IC}\end{array}$} \\
\hline & $\mathrm{M}$ & $\mathrm{SD}$ & $\mathrm{n}$ & $\mathrm{M}$ & $\mathrm{SD}$ & $\mathrm{n}$ & & & \\
\hline Ando et al. (2007) & 0,96 & 1,58 & 52 & 0,85 & 1,26 & 52 & 26,1 & $0,11\lceil-0,44,0,66\rceil$ & $\rightarrow$ \\
\hline Baldry \& Farrington (2004) ${ }^{1}$ & 2,69 & 3,31 & 58 & 1,57 & 2,20 & 72 & 17,7 & $1,12[0,13,2,11]$ & \\
\hline Baldry \& Farrington $(2004)^{2}$ & 2,31 & 3,07 & 63 & 3,39 & 3,99 & 36 & 10,9 & $-1,08[-2,59,0,43]$ & T. \\
\hline DeRosier (2004) & 0,15 & 1,22 & 187 & 0,07 & 1,13 & 194 & 31,6 & $0,08[-0,16,0,32]$ & t. \\
\hline Stan \& Beldean (2014) & 5,38 & 4,82 & 115 & 7,08 & 4,99 & 117 & 13,7 & $-1,70[-2,96,-0,44]$ & - \\
\hline Total & & & 475 & & & 475 & 100 & $-0,10[-0,71,0,51]$ & - \\
\hline
\end{tabular}

Figure 2. Forest Plot for the mean differences concerning decreased aggressive behavior after social skills interventions.

The results presented by Figure 2 show nonsignificant effects of interventions intended to decrease episodes of aggression, with combined mean difference: -0.10 (CI95\%: -0.71, 0.51). Heterogeneity was found among studies; that is, high variability was found $\left(\mathrm{I}^{2}=71.75 \%\right)$, which justified the DerSimonian-Laird test. 


\begin{tabular}{|c|c|c|c|c|c|c|c|c|c|}
\hline \multirow[t]{2}{*}{ Study } & \multicolumn{3}{|c|}{ Intervention } & \multicolumn{3}{|c|}{ Control } & \multirow{2}{*}{$\begin{array}{l}\text { Weigth } \\
(\%)\end{array}$} & \multirow{2}{*}{$\begin{array}{c}\text { Difference } \\
95 \% \mathrm{IC}\end{array}$} & \multirow{2}{*}{$\begin{array}{c}\text { Difference } \\
95 \% \mathrm{IC}\end{array}$} \\
\hline & M & $\mathrm{SD}$ & $\mathrm{n}$ & M & SD & $\mathrm{n}$ & & & \\
\hline Baldry \& Farrington (2004) ${ }^{1}$ & 3,66 & 4,36 & 59 & 1,85 & 2,62 & 71 & 15 , & $0,39\lceil-1,02,1,80]$ & \\
\hline Baldry \& Farrington $(2004)^{2}$ & 3,64 & 4,89 & 64 & 2,79 & 2,48 & 38 & 21,3 & $-0,48[-1,58,0,62]$ & 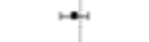 \\
\hline Berry \& Hunt (2009) & 15,91 & 7,05 & 22 & 12,58 & 5,98 & 24 & 3,5 & $-5,04[-8,64,-1,44]$ & \\
\hline DeRosier (2004) & 0,31 & 1,10 & 187 & 0,26 & 1,12 & 194 & 42,0 & $0,12[-0,11,0,35]$ & - \\
\hline Fox \& Boulton (2003) & 29,47 & 8,16 & 15 & 33,56 & 20,15 & 13 & 0,3 & $0,73[-12,89,14,35]$ & \\
\hline Stan \& Beldean (2014) & 7,79 & 6,18 & 115 & 7,57 & 4,98 & 117 & 17,0 & $-0,14[-1,48,1,20]$ & $\ldots$ \\
\hline Total & & & 462 & & & 457 & 100 & $-0,19[-0,89,0,52]$ & - \\
\hline
\end{tabular}

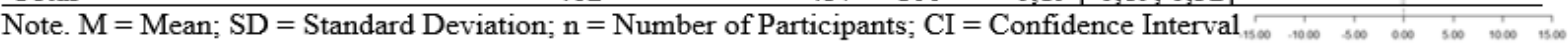

Hetererogeneity: $Q=9,18, d f=5(p=0,10) ; I^{2}=45,52 \%$

Test for overall effect: $Z=-0,5259(p=0,59)$

Figure 3. Forest Plot for the mean differences concerning reduced victimization after social skills interventions.

In Figure 3, Cochran's Q test was performed to verify the heterogeneity of the results obtained by the interventions intended to decrease victimization and reveals a combined mean difference of -0.19 (CI95\% $-0.89,0.52)$, with 5 degrees of freedom, without statistical significance. Heterogeneity was low among the studies $\left(\mathrm{I}^{2}=45.52 \%\right)$. Joint comparison of the studies shows that the social skills interventions did not significantly reduce victimization.

\section{Discussion}

This study's objective was to verify whether the interventions focused on social skills reduced bullying victimization and/or bullying aggression. The small number of studies with an experimental or quasi-experimental design $(n=6)$ identified in the databases shows that the interventions focusing on social skills to prevent or decrease bullying are seldom developed with more rigorous methodological designs. This is perhaps explained by the divergent results reported by studies with similar design or by indications reported in the literature that schoolwide interventions involving students, families, teachers and the remaining members of the school community achieve more promising results because they include a variety of situations, contexts and subjects implicated in bullying (Olweus, 2013).

Hence, focal interventions directed to specific groups, such as students, the preferred population of social skills programs, are seldom implemented because they present less-positive results
(Ttofi \& Farrington, 2011). The fact the studies addressed in this review are relatively recent is perhaps due to these reasons, once school-wide interventions, such as the one proposed by the Olweus Bullying Prevention Program (OBPP), were developed in the 1980s (Olweus, 2013); the oldest study addressing social skills identified in this review was published in 2003.

The interventions presented sufficient methodological quality. All met more than $70 \%$ of the 27 characteristics assessed, ensuring greater reliability of results, even though some studies did not take into account confounding variables that could have interfered in their results, did not report sample losses or randomization effects, and most did not present the study's statistical power.

Another relevant aspect is the variety of sociocultural contexts (different countries) in which the interventions were implemented; that is, success achieved by a given intervention in a given context does not ensure similar results will be achieved in another context, due to existing differences (Napolitano, Espelage, Vaillancourt, \& Hymel, 2010). One example of such an aspect is the OBPP, which presents divergent results depending on the country in which it was implemented. Greater success was achieved in European countries, while almost null effect was found in the United States, a country in which most anti-bullying interventions achieve lesser results (Ttofi \& Farrington, 2011).

In general, an analysis of all the studies selected shows that the effectiveness of interventions varied among situations. In some cases, 
bullying (victimization or aggressions) did not decrease significantly (Ando et al., 2007; Fox \& Bouton, 2003), while in other cases, it decreased significantly (Baldry \& Farrington, 2004; Berry \& Hunt, 2009; DeRosier, 2004; Stan \& Beldean, 2014).

The meta-analysis concerning the effects of interventions addressing social skills to reduce victimization did not show significant differences, though some studies did report a decrease. The literature shows that victimization should decrease when interventions designed to improve the social skills and competence of students are implemented, considering that this type of intervention is supposed to improve social skills, assertiveness, and behaviors that tend to lead to social isolation (Fox \& Boulton, 2003; Stan \& Beldean, 2014).

This apparent contradiction - the lack of a significant decrease in victimization - may be explained when we consider that bullying is a group phenomenon influenced by the characteristics of the contexts in which it occurs, such as within classrooms or in the entire school, restricting any real possibility of a child or adolescent overcoming by themselves a behavior that is widely accepted or encouraged by peers (Wölfer \& Scheithauer, 2014). Hence, even assertive responses to abusive behavior may not be effective in a context in which violence is considered the rule.

In terms of the methodology of interventions addressing social skills, the difficulty in generalizing recently learned skills in real routine situations is an aspect that has already been acknowledged (Silva et al., 2016). Role-play techniques have been suggested as a strategy to overcome this difficulty, as students have a chance to experience a closer proximity to real situations they face in their school context during the intervention (Leadbeater \& Hoglund, 2006), which is not always an easy task if bullying is considered the rule among peers. Additionally, grouping individuals with similar characteristics (only victims or only bullies) may negatively impact the development of activities, impairing the intervention's results.
In any case, reduced victimization, even if modest, should be valued as it is a sign of the possible success of this modality of intervention. An important step to be taken consists of improving interventions to more precisely identify whether a small reduction occurs due to methodological problems or to the planning of interventions or due to the reasons previously mentioned. As already discussed, even broader interventions, such as school-wide programs, present divergent results, depending on the context. Future studies can help to clarify these issues.

The meta-analysis results concerning the effect of the interventions on specifically decreasing bullying was not significant for the experimental groups in comparison to the control groups. A similar result is reported by another meta-analysis conducted by Ttofi and Farrington (2011), which assessed the effectiveness of different interventions in reducing bullying: interventions focused on social skills did not report significant a decrease of aggression episodes.

Therefore, bullying may not be linked to the development of social skills. This result is in agreement with some studies in which bullies are not identified as having poor social skills (Napolitano et al., 2010; Thunfors \& Cornell, 2008). Note, however, that the literature addressing the social skills of bullies presents divergent results. Studies adopting non-experimental designs report a decrease of up to $50 \%$ in abusive behavior or a lack of significant effects (Kõiv, 2012).

Even though the small number of interventions addressing this topic is a factor that limits more precise identification of the effects on bullying, when individually analyzed, some interventions present significant results. The decrease presented by these studies on abuse may be partially explained by the decision to include in the interventions groups of students with different behaviors toward bullying. Such a decision may have avoided bullies, that is, those who more frequently practice abusive behavior having their aggressive behavior against each other being reinforced, as well as may have offered an opportunity to these individuals to have greater 
contact with peers who represented a model of pro-social behavior (Napolitano et al., 2010). Among the papers under analysis, the three studies that individually presented a statistically significant decrease of abuse (Baldry \& Farrington, 2004; DeRosier, 2004; Stan \& Beldean, 2014) adopted mixed intervention groups.

Another possible explanation is that the newly learned social skills may have enabled the manifestation of non-aggressive responses in the social relationships among students, especially bullies, so that they were more easily accepted by their peers (Leadbeater \& Hoglund, 2006). A similar result was found in a non-experimental study conducted by Murrieta, Ruvalcaba, Caballo and Lorenzo (2014), which reports a significant decrease of direct abuse $(p<.01)$ and relational abuse $(p<.05)$ in the group of abusers.

Another piece of information that draws attention in the analysis of the revised studies is that the interventions obtained the most extensive effects among older students. Most of the revised studies, however, focused on samples composed of participants aged older than 10 years, which restricts the interpretation of this specific result, as it may be biased by the amount of studies addressing older individuals. Despite this limitation, a potential explanation would be the fact that older students present more developed cognitive skills, which enable them to understand, learn and put social skills into practice, as well as to assess the harmful nature of bullying. Another possibility is that, in the case of older students being victims, they are more physically developed or would be able to make more rational decisions, which perhaps enables them to defend themselves more efficiently and deal with abusive behavior more effectively when interacting with peers (Baldry \& Farrington, 2004).

One limitation identified in the studies is a lack of follow up, considering that some behavioral changes require time to develop. Hence, improved skills may impact other aspects of the lives of students and social relationships until they play an effective role in the situations of violence they experience or practice. Hence, other dimensions of the students' lives directly connected to social skills, such as a broader net- work of peers, may positively impact bullying situations over time, resulting in lower levels of violence among students (Fox \& Boulton, 2003).

Another limitation of the studies analyzed in this review is that participants were not differentiated as to their status as victims, bullies or bystanders. As important as it is to identify significant decreases in victimization or abuse, it is also important to verify the mobility of children and adolescents among the different conditions, that is, to verify how many are no longer bullies or victims. This is relevant information because the amount of victims may significantly decrease but not necessarily be accompanied by a significant decrease in victimization. The reason is that, even though there may be fewer victims, these may experience more intensive abuse. The same applies to the number or frequency of abusive episodes. Future studies can attempt to fill in this gap.

The small sample sizes hinder the generalization of results because none of the studies was developed with a representative sample, while some were pilot studies. Investigations with larger samples are needed, as well as studies developed in Brazil, since no Brazilian study was identified in the databases used. Another limitation is the grouped analysis of the interventions' effects for boys and girls. Because abuse and responses to intimidation are equally modulated by issues related to the sex of the individuals (Sentse, Kretschmer, \& Salmivalli, 2015), there is a need to attain a deeper understanding of the effects of interventions on the social skills of boys and girls in regard to bullying. Future studies can also advance in this direction, incorporating the differences between sexes in the analysis of results.

\section{Final Considerations}

The interventions analyzed in this review present divergent results in regard to decreased bullying, while only some of them individually present positive and significant effects. The meta-analysis, however, did not reveal statistical significance. One limitation of this review is the high level of heterogeneity found among the 
studies addressing abuse, even though only studies with the same methodological design were included and the meta-analysis used a random effect model along with the DerSimonian-Laird test to analyze random effect, which considers the variation in each study, as well as differences among studies in the analysis of the effect of interest. Therefore, it is important to highlight that these specific results should be carefully interpreted, avoiding generalizations. Considering the relevance of this topic, the need to perform further studies using experimental or quasiexperimental designs and larger samples, especially those implemented in Brazil, is reinforced in order to overcome the aforementioned limitations and obtain more robust results.

\section{References}

Ando, M., Asakura, T., Ando, S., \& Simons-Morton, B. (2007). A psychoeducational program to prevent aggressive behavior among Japanese early adolescentes. Health Education \& Behavior, 34(5), 765-776. doi:10.1177/1090198106291965

Baldry, A. C., \& Farrington, D. P. (2004). Evaluation of an intervention program for the reduction of bullying and victimization in schools. Aggressive Behavior, 30(1), 1-15. doi:10.1002/ ab. 20000

Benedict, F. T., Vivier, P. M., \& Gjelsvik, A. (2015). Mental health and bullying in the United States among children aged 6 to 17 years. Journal of Interpersonal Violence, 30(5), 782-795. doi:10.1177/0886260514536279

Berry, K., \& Hunt, C. J. (2009). Evaluation of an intervention program for anxious adolescent boys who are bullied at school. Journal of Adolescent Health, 45(4), 376-382. doi:10.1016/j.jadohealth.2009.04.023

Crawford, A. M., \& Manassis, K. (2011). Anxiety, social skills, friendship quality, and peer victimization: An integrated model. Journal of Anxiety Disorders, 25(7), 924-931. doi:10.1016/j.janxdis.2011.05.005

Del Prette, Z. A. P., \& Del Prette, A. (2013). Psicologia das habilidades sociais na infância: Teoria e prática. Petrópolis, RJ: Vozes.

DeRosier, M. E. (2004). Building relationships and combating bullying: Effectiveness of a school- based social skills group intervention. Journal of Clinical Child \& Adolescent Psychology, 33(1), 196-201. doi:10.1207/S15374424JCCP3301_18

Downs, S. H., \& Black, N. (1998). The feasibility of creating a checklist for the assessment of the methodological quality both of randomised and non-randomised studies of health care interventions. Journal of Epidemiology and Community Health, 52(6), 377-384.

Due, P., Holstein, B. E., Lynch, J., Diderichsen, F., Gabhain, S. N., Scheidt, P., \& Currie, C. (2005). Bullying and symptoms among school-aged children: International comparative cross sectional study in 28 countries. The European Journal of Public Health, 15(2), 128-132. doi:10.1093/eurpub/cki105

Fox, C., \& Boulton, M. (2003). Evaluating the effectiveness of a Social Skills Training (SST) programme for victims of bullying. Educational Research, 45(3), 231-247. doi:10.1080/0013188032000137238

Galvão, T. F., \& Pereira, M. G. (2014). Revisões sistemáticas da literatura: Passos para sua elaboração. Epidemiologia e Serviços de Saúde, 23(1), 183-184. doi:10.5123/S167949742014000100018

Higgins, J. P. T., \& Thompson, S. G. (2002). Quantifying heterogeneity in a metaanalysis. Statistics in Medicine, 21, 1539-1558. doi:10.1002/ sim. 1186

Kõiv, K. (2012). Social Skills Training as a mean of improving intervention for bullies and victims. Procedia - Social and Behavioral Sciences, 45, 239-246. doi:10.1016/j.sbspro.2012.06.560

Leadbeater, B., \& Hoglund, W. (2006). Changing the social contexts of peer victimization. Journal of the Canadian Academy of Child and Adolescent, 15(1), 21-26.

Murrieta, P., Ruvalcaba, N. A., Caballo, V. E., \& Lorenzo, M. (2014). Cambios en la percepción de la violencia y el comportamiento agresivo entre niños a partir de un programa de habilidades socioemocionales. Psicología Conductual, 22(3), 569-584.

Napolitano, S. M. S., Espelage, D. L., Vaillancourt, T., \& Hymel, S. (2010). What can be done about school bullying? Linking research to educational practice. Educational Researcher, 39(1), 38-47. doi:10.3102/0013189X09357622 
Oliveira, W. A., Silva, M. A. I., Mello, F. C. M., Porto, D. L., Yoshinaga, A. C. M., \& Malta, D. C. (2015). Causas do bullying: Resultados da Pesquisa Nacional de Saúde do Escolar. Revista Latino-Americana de Enfermagem, 23(2). doi:10.1590/0104-1169.0022.2552

Olweus, D. (2013). School bullying: Development and some important challenges. Annual Review of Clinical Psychology, 9, 751-780. doi:10.1146/ annurev-clinpsy-050212-185516

Santos, C. M. C., Pimenta, C. A. M., \& Nobre, M. R. C. (2007). A estratégia PICO para a construção da pergunta de pesquisa e busca de evidências. Revista Latino-Americana de Enfermagem, 15(3), 508-511. doi:10.1590/S010411692007000300023

Sentse, M., Kretschmer, T., \& Salmivalli, N. (2015). The longitudinal interplay between bullying, victimization, and social status: Age-related and gender differences. Social Development, 24(3), 659-677. doi:10.1111/sode. 12115

Silva, J. L., \& Bazon, M. R. (2014). Educação escolar e conduta infracional em adolescentes: Revisão integrativa da literatura. Estudos de Psicologia (Natal), 19(4), 278-287. doi:10.1590/S1413294X2014000400005

Silva, J. L., Oliveira, W. A., Braga, I. F., Farias, M. S., Silva Lizzi, E. A., Gonçalves, M. F. C., ...Silva, M. A. I. (2016). The effects of a skill-based intervention for victims of bullying in Brazil. International Journal of Environmental Research and Public Health, 13, 1042-1052. doi:10.3390/ ijerph13111042

Silva, J. L., Oliveira, W. A., \& Longarezi, A. M. (2008). O bullying e suas interferências nos processos de ensino-aprendizagem. Revista da Sociedade de Psicologia do Triângulo Mineiro, 12(2), 177-185.

Silva, M. A. I., Silva, J. L., Pereira, B. O., Oliveira, W. A., \& Medeiros, M. (2014). The view of teachers on bullying and implications for nursing. Revista da Escola de Enfermagem da USP, 48(4), 723 730. doi:10.1590/S0080-623420140000400021
Skrzypiec, G., Slee, P., Murray-Harvey, R., \& Pereira, B. (2011). School bullying by one or more ways: Does it matter and how do students cope? School Psychology International 32(3), 288-311. doi:10.1177/0143034311402308

Stan, C., \& Beldean, I. G. (2014). The development of social and emotional skills of students - Ways to reduce the frequency of bullying-type events. Experimental results. Procedia - Social and Behavioral Sciences, 114, 735-743. doi:10.1016/j. sbspro.2013.12.777

Thunfors, P., \& Cornell, D. (2008). The popularity of middle school bullies. Journal of School Violence, 7(1), 65-82. doi:10.1300/J202v07n01_05

Ttofi, M. M., \& Farrington, D. P. (2011). Effectiveness of school-based programs to reduce bullying: A systematic and meta-analytic review. Journal of Experimental Criminology, 7(1), 2756. doi:10.1007/s11292-010-9109-1

Viechtbauer, W. (2010). Conducting meta-analyses in $\mathrm{R}$ with the metafor package. Journal of Statistical Software, 36(3), 1-48. doi:10.18637/jss. v036.i03

Wölfer, R., \& Scheithauer, H. (2014). Social influence and bullying behavior: Intervention-based network dynamics of the fairplayer.manual bullying prevention program. Aggressive Behavior, 40(4), 309-331. doi:10.1002/ab.21524

(C) The Author(s), 2018. Open Access. This article is distributed under the terms of the Creative Commons Attribution 4.0 International License (http://creativecommons.org/licenses/by/4.0/), which permits unrestricted use, distribution, and reproduction in any medium, provided you give appropriate credit to the original author(s) and the source, provide a link to the Creative Commons license, and indicate if changes were made. 